\title{
Defective Titanium Dioxide-supported Ultrasmall Au Clusters for Photocatalytic Hydrogen Production
}

\author{
Xiaoqin Zhang ${ }^{1}$, Wenna Zhang ${ }^{1}$, Yuanmei $\mathrm{Xu}^{1,2,3 *}$ and Mingliang $\mathrm{Jin}^{1,2 *}$ \\ ${ }^{1}$ National Center for International Research on Green Optoelectronics, South China Academy of Advanced Optoelectronics, \\ South China Normal University, Guangzhou, China, ${ }^{2}$ International Academy of Optoelectronics at Zhaoging, South China Normal \\ University, Guangdong, China, ${ }^{3}$ State Key Lab of Silicon Materials, Zhejiang University, Hangzhou, China
}

Ultrasmall precious metal clusters have attracted extensive attention for providing a very specific surface and promoting electron transfer. In this work, ultrasmall $\mathrm{Au}$ clusters based on defective $\mathrm{TiO}_{2}$ nanosheets $\left(\mathrm{Au} / \mathrm{D}-\mathrm{TiO}_{2}\right)$ were prepared and introduced into photocatalytic hydrogen evolution. Different defects of $\mathrm{TiO}_{2}$ nanosheets $\left(\mathrm{D}-\mathrm{TiO}_{2}\right)$ were constructed using a heating process and then loaded with $\mathrm{Au}$ clusters. Compared with bare $\mathrm{TiO}_{2}$, Au clusters established on defective $\mathrm{TiO}_{2}$ nanosheets with a narrower band gap showed higher light absorption

OPEN ACCESS

Edited by:

Chongfu Zhang,

University of Electronic Science and

Technology of China, China

Reviewed by:

Xiaolei Wang,

University of Alberta, Canada

Yongchao Huang,

Guangzhou University, China

*Correspondence:

Mingliang Jin

jinm/@scnu.edu.cn

Yuanmei Xu

yuanmei.xu@ecs-scnu.org

Specialty section:

This article was submitted to

Optics and Photonics,

a section of the journal

Frontiers in Physics

Received: 12 October 2020 Accepted: 02 November 2020

Published: 25 November 2020

Citation:

Zhang $X$, Zhang $W, X u Y$ and Jin $M$ (2020) Defective Titanium Dioxidesupported Ultrasmall Au Clusters for Photocatalytic Hydrogen Production.

Front. Phys. 8:616349.

doi: 10.3389/fphy.2020.616349 performances, resulting in obviously enhanced photocatalytic hydrogen production performances. The $\mathrm{Au} / \mathrm{D}-\mathrm{TiO}_{2}$ displayed the greatly enhanced photocatalytic hydrogen evolution activity of $3,142.33 \mu \mathrm{mol} \mathrm{h}{ }^{-1} \mathrm{~g}^{-1}$, which was over 45 times than the pure $\mathrm{TiO}_{2}$. The results showed that the catalysts had good prospects in the field of photocatalytic hydrogen production.

Keywords: $\mathrm{Au}$, cluster, defect $\mathrm{TiO}_{2}, \mathrm{H}_{2}$ evolution, photocatalytic

\section{INTRODUCTION}

Photocatalytic $\mathrm{H}_{2}$ evolution, which utilizes water decomposition under solar energy, is a promising route to overcome the growing energy crisis and environment issues. However, in this process, the photocatalyst plays a key role. At present, photocatalysts such as nitrides [1,2], metal sulfides $[3,4]$, and metal oxides $[5,6]$ have been demonstrated in hydrogen evolution systems. Among the traditional photocatalysts, anatase is one of the most extensively studied photocatalysts due to its reasonable price, nontoxicity, and remarkable photochemical stability $[7,8]$. However, $\mathrm{TiO}_{2}$ with a comparatively large band gap $(3.2 \mathrm{eV})$ can absorb only the ultraviolet portion of the solar spectrum, resulting in insufficient photocatalytic activity of $\mathrm{TiO}_{2}$ for $\mathrm{H}_{2}$ production.

Photocatalytic efficiency of $\mathrm{TiO}_{2}$ for water decomposition is limited due to the high recombination rate of photogenerated carriers. Hence, many measures have been taken to solve the problem of low photocatalytic performance of $\mathrm{TiO}_{2}$, involving the mingling of transition metals $[9,10]$, adding of the nonmetal ions $[11,12]$, loading of the precious metals $[13,14]$, the surface for dye-sensitized [15], and the generation of hybrid semiconductor [16, 17]. The manufacture of metalsemiconductor oxide composite materials is another very dynamic research area that can improve the photocatalytic activity of semiconductor oxide photocatalysts [18]. It has been reported that the transfer of electrons from semiconductor oxides to metals may reduce electron hole recombination events and improve the photocatalytic performances of semiconductor oxide-based catalysts. Thus, the electron hole pairs in the recombined semiconductor oxide produced by photons can be reduced by a large part $[19,20]$. 

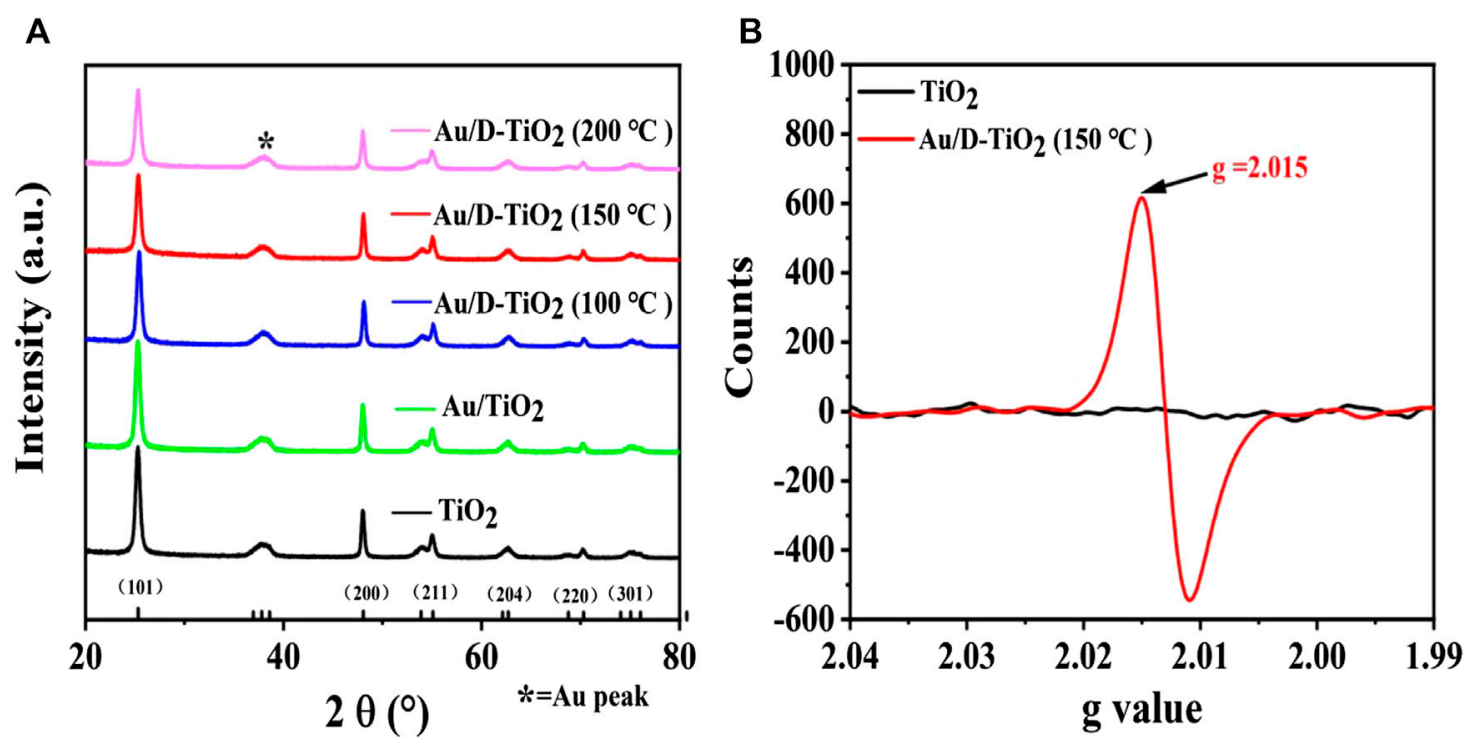

FIGURE 1 | (A) XRD of pure $\mathrm{TiO}_{2}, \mathrm{Au} / \mathrm{TiO}_{2}$, and $\mathrm{Au} / \mathrm{D}-\mathrm{TiO}_{2}\left(\mathrm{The} \mathrm{D}-\mathrm{TiO}_{2}\right.$ were treated at $100^{\circ}, 150^{\circ}$, and $200^{\circ} \mathrm{C}$, respectively) (B) $\mathrm{EPR}$ of TiO ${ }_{2}$ and $\mathrm{Au} / \mathrm{D}-\mathrm{TiO}{ }_{2}$ (treated at $\left.150^{\circ} \mathrm{C}\right)$.

Therefore, in this work, the electron hole recombination rate was reduced, we have demonstrated a method of constructing defects on metal oxides to support Au clusters. Both oxygen vacancies and a $\mathrm{Ti}-\mathrm{O}$-Ti structure were formed in this process. Oxygen atoms were lost through the formed oxygen vacancies, and the original oxygen vacancies were occupied by metal clusters, thus effectively reducing the recombination rate of photogenerated carriers. Au clusters built on defective $\mathrm{TiO}_{2}$ nanosheets $\left(\mathrm{Au} / \mathrm{D}-\mathrm{TiO}_{2}\right)$ were applied to the production of photocatalytic hydrolysis hydrogen and showed significantly enhanced performances. Compared with the traditional $\mathrm{TiO}_{2}$ catalyst, the catalysts of $\mathrm{Au} / \mathrm{D}-\mathrm{TiO}_{2}$ could produce up to 45 times more hydrogen than $\mathrm{TiO}_{2}$. The results demonstrated that the structural defects on the surface of metal oxide could improve the catalytic performance of $\mathrm{Au} / \mathrm{D}-\mathrm{TiO}_{2}$ catalysts. This work laid a foundation for the preparation of catalysts in the future.

\section{EXPERIMENTAL SECTION}

\subsection{Materials}

The chemical reagents Tetra-n-butyl Titanate $\left(\mathrm{Ti}\left(\mathrm{OC}_{4} \mathrm{H}_{9}\right)_{4}\right.$, 99.0\%, AR grade), hydrofluoric acid solution (HF, $40.0 \mathrm{wt} \%$, AR grade), ethanol (99.7\%, AR grade), and ammonium carbonate (40\%, AR grade) were bought from Tianjin Damao Chemical Reagent Factory, China. $\mathrm{HAuCl}_{4} \cdot 3 \mathrm{H}_{2} \mathrm{O}$ (99.9\%, AR grade) was bought from Aladdin, China. All experimental materials were used directly in the experiment after purchase.

\subsection{Sample Preparation}

\subsubsection{Preparation of $\mathrm{D}-\mathrm{TiO}_{2}$ Nanosheets}

$\mathrm{TiO}_{2}$ nanosheets were obtained by hydrothermal method. In a common synthesis, $\mathrm{Ti}\left(\mathrm{OC}_{4} \mathrm{H}_{9}\right)_{4}(50 \mathrm{ml})$ and $\mathrm{HF}(6 \mathrm{ml})$ were added to the Teflon-lined autoclave. Then, the hydrothermal reaction occurred at $180^{\circ} \mathrm{C}$ for $24 \mathrm{~h}$. After the reaction, the white sediment of the Teflon-lined autoclave was centrifuged and rinsed three times with water and ethanol, and dried in an oven at a temperature of $80^{\circ} \mathrm{C}$ for $12 \mathrm{~h}$. Different defects of $\mathrm{D}-\mathrm{TiO}_{2}$ sample were obtained after being calcined at reducing atmosphere (10 vol.\% $\mathrm{H}_{2}$ and 90 vol.\% $\mathrm{Ar}, 2 \mathrm{~h}$ ) with unequal temperatures (The $\mathrm{D}-\mathrm{TiO}_{2}$ were treated at $100^{\circ}, 150^{\circ}$, and $200^{\circ} \mathrm{C}$, respectively).

\subsubsection{Synthesis of $\mathrm{Au} / \mathrm{D}-\mathrm{TiO}_{2}$}

$\mathrm{Au} / \mathrm{D}-\mathrm{TiO}_{2}$ was composite according to the depositionprecipitation method. First, $1 \mathrm{~g}$ of pure or defective $\mathrm{TiO}_{2}$ nanosheets powders were suspended in $50 \mathrm{ml}$ distilled water and stirred for $20 \mathrm{~min}$. Then, the aqueous solution $(25 \mathrm{ml})$ of

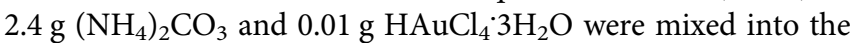
above solution drop by drop and stirred for $1 \mathrm{~h}$ at room temperature. And then, the samples were collected by centrifugation, and washed with distilled water and ethanol for three times, respectively. $\mathrm{Au} / \mathrm{D}-\mathrm{TiO}_{2}$ samples were gained after being dried at $70^{\circ} \mathrm{C}$ for $6 \mathrm{~h}$ and calcined $\left(200^{\circ} \mathrm{C}, 10\right.$ vol. $\% \mathrm{H}_{2}$ and 90 vol. $\%$ Ar) for $2 \mathrm{~h}$. For comparison, $\mathrm{Au} / \mathrm{TiO}_{2}$ was synthesized with the same method on $\mathrm{TiO}_{2}$ nanosheets instead of $\mathrm{D}-\mathrm{TiO}_{2}$.

\subsubsection{Characterization}

The crystalline structures of the acquired samples were analyzed by a powder X-ray diffractometer (XRD, BRUKER D8 ADVANCE) with a scan range of $10^{\circ}-90^{\circ}$ and a step size of $0.02^{\circ}$. The measurement of electron paramagnetic resonance (EPR) was performed at room temperature using a BRUKE A300 EPR spectrometer. The transmission electron microscopy (TEM) and high angle annular dark-field (HAADF) were performed on a JEM-2100HR operating at 


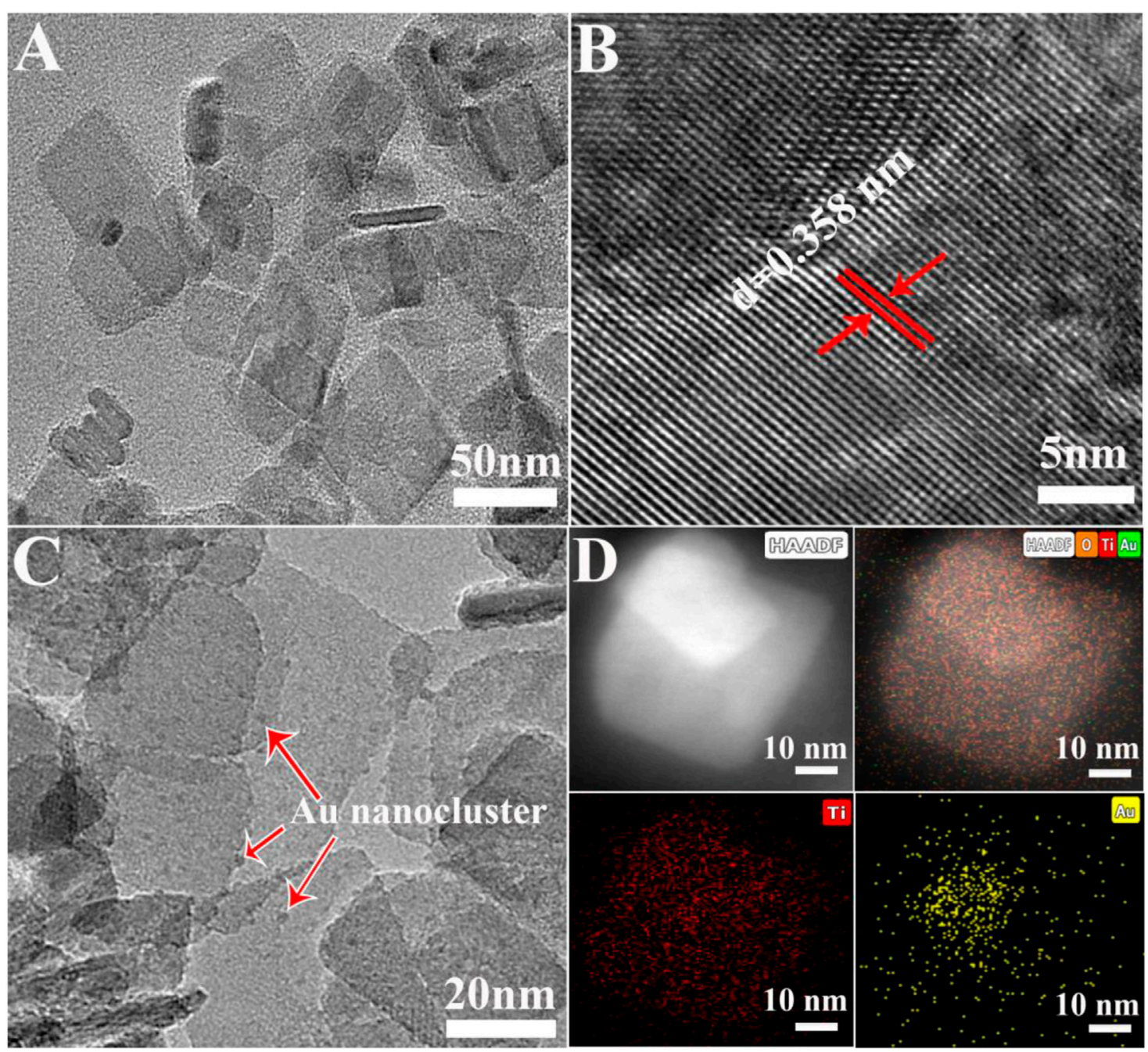

FIGURE 2 | (A) TEM image of $\mathrm{TiO}_{2}$ nanosheets (B) HRTEM image of the selective area (C) TEM image, Au clusters high-lighted by red arrows (D) elemental mappings show the distribution of $\mathrm{Ti}$ (red) and $\mathrm{Au}$ (gold).

$200 \mathrm{kV}$. The surface analysis of every sample was examined by $\mathrm{X}$-ray photoelectron spectroscopy (XPS) using a Thermo Fisher Scientific K-Alpha spectrometer. The Metal contents of samples were analyzed by analysis of inductively coupled plasma spectroscopy (ICP, Agilent 700). The UV-vis diffuse reflectance spectra (DRS) recorded on a Lambda 750 spectrophotometer. The photoluminescence (PL) spectra gained by a F-4600 FL Spectrophotometer.

\subsubsection{Photocatalytic Hydrogen Evolution}

The photocatalytic hydrolysis reaction was carried out in a heatresistant glass reactor, which was connected to a sealed single channel glass system, a circulating water system, a controller, and a vacuum pump. A $300 \mathrm{w}$ xenon lamp was applied as a light source and fixed with the distance of $1 \mathrm{~cm}$ from the glass reactor. The glass reactor was charged with $80 \mathrm{ml}$ of distilled water, $20 \mathrm{ml}$ of methanol solution and $50 \mathrm{mg}$ of photocatalyst.
Before the start of the reaction, in order to keep the entire reaction device free of air, the vacuum pump was turned on for $1 \mathrm{~h}$, and the valves of the glass system were rotated while evacuating, and the air of the system was extracted as much as possible. The circulating water and the controller were opened while the vacuum pump was being punched, and the magnetic stirrer placed under the glass reactor was turned at $500 \mathrm{rpm}$ to avoid overheating of the reaction during the experiment and to guarantee uniform dispersion of the photocatalyst in the solution. In the photocatalytic hydrogen production experiment, a gas chromatograph was used to analyze the produced hydrogen gas, and the gas chromatograph was equipped with a packed bed column having a temperature of $70^{\circ} \mathrm{C}$ and a detector. In the hydrogen production experiment, the xenon lamp irradiation time was $1 \mathrm{~h}$ for each time, and the intake air was detected every hour with a total of $4 \mathrm{~h}[21,22]$. 

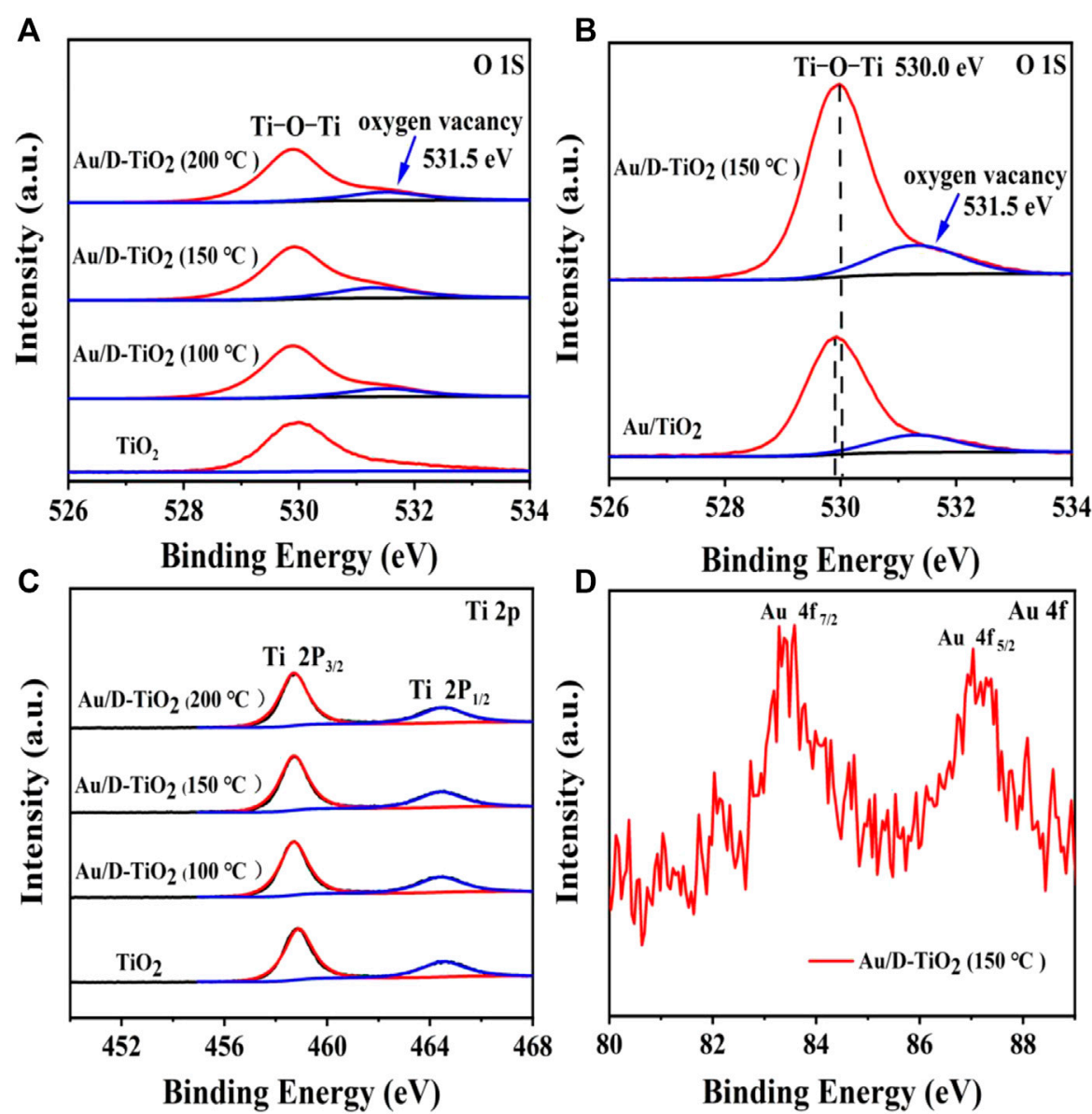

FIGURE 3 | (A) XPS of $\mathrm{TiO}_{2}$ and D- $\mathrm{TiO}_{2}$ (The D- $\mathrm{TiO}_{2}$ were treated at $100^{\circ}, 150^{\circ}$, and $200^{\circ} \mathrm{C}$, respectively) (B) XPS of synthesized Au/TiO 2 and Au/D-TiO ${ }_{2}$ (treated at $\left.150^{\circ} \mathrm{C}\right)$ (C) Ti $2 \mathrm{p}$ spectrum (D) Au $4 \mathrm{f}$ spectrum.

\section{RESULTS AND DISCUSSION}

The compositions and phase structures of the samples were studied by using XRD (Figure 1). It could be seen from the XRD patterns that both pure and defective $\mathrm{TiO}_{2}$ were with a palpable structure of anatase phase (JCPDS no. 21-1272). In the case of $\mathrm{Au} / \mathrm{D}-\mathrm{TiO}_{2}$, the crystallographic peaks of $\mathrm{Au}$ could be detected (Figure 1A). Defects in $\mathrm{D}-\mathrm{TiO}_{2}$ were tested by electron paramagnetic resonance (EPR) measurements (Figure 1B), which indicated an aerobic vacancy defect with a $\mathrm{g}$ value of 2.015 [23-25].

The preparation of defective $\mathrm{TiO}_{2}$ was the first and an important step in the synthesis process of the catalyst $\mathrm{Au} /$ $\mathrm{D}-\mathrm{TiO}_{2}$. The transmission electron microscopy (TEM) image (Figure 2A) demonstrated the nanosheet structure of $\mathrm{D}-\mathrm{TiO}_{2}$ with a length of about $50 \mathrm{~nm}$. And the high-resolution transmission electron microscopy (HRTEM) showed a lattice spacing of approximate $0.358 \mathrm{~nm}$ (Figure 2B) corresponding to (101) planes of $\mathrm{TiO}_{2}$. In addition, Figure 2C had many $\mathrm{Au}$ clusters distributed and marked by the red arrow. Further, the high angle annular dark-field (HAADF) and the element mapping image (Figure 2D) further indicated that the $\mathrm{Au}$ clusters were well dispersed on the defective $\mathrm{TiO}_{2}$ carrier.

In order to further explore the surface defects of the pure $\mathrm{TiO}_{2}$ and the defective $\mathrm{TiO}_{2}$, the X-ray photoelectron spectroscopy (XPS) spectra were conducted. The O 1 score-level XPS spectrum manifested two peaks in Figure 3A, one of which at $530.0 \mathrm{eV}$ was considered as the oxygen band of Ti-O-Ti, and another one at $531.5 \mathrm{eV}$ could be attributed to oxygen vacancy. The peak area of $531.5 \mathrm{eV}$ of $150^{\circ} \mathrm{C}$ treated sample was larger than that of the other samples, indicating the highest oxygen vacancy concentration (Figure 3A). Figure 3B showed the $\mathrm{O} 1 \mathrm{~s}$ XPS spectrum of $\mathrm{Au} /$ $\mathrm{TiO}_{2}$ and $\mathrm{Au} / \mathrm{D}-\mathrm{TiO}_{2}$ (treated at $150^{\circ} \mathrm{C}$ ). It was found that the binding energy of $\mathrm{Au} / \mathrm{D}-\mathrm{TiO}_{2}$ was significantly shifted to higher binding energies compared with $\mathrm{Au} / \mathrm{TiO}_{2}$. And the strength of Ti-O$\mathrm{Ti}$ of $\mathrm{Au} / \mathrm{D}-\mathrm{TiO}_{2}$ (treated at $150^{\circ} \mathrm{C}$ ) was greater than that of $\mathrm{Au} /$ $\mathrm{TiO}_{2}$. Usually, such binding energy transfer is explained by a strong interaction between the two components. Figure $3 \mathrm{C}$ displayed the $\mathrm{Ti}$ $2 \mathrm{p} \mathrm{XPS}$ spectrum of $\mathrm{TiO}_{2}$ and $\mathrm{Au} / \mathrm{D}-\mathrm{TiO}_{2}\left(\mathrm{The} \mathrm{D}-\mathrm{TiO}_{2}\right.$ were treated at $100^{\circ}, 150^{\circ}$, and $200^{\circ} \mathrm{C}$, respectively) and demonstrated that they 

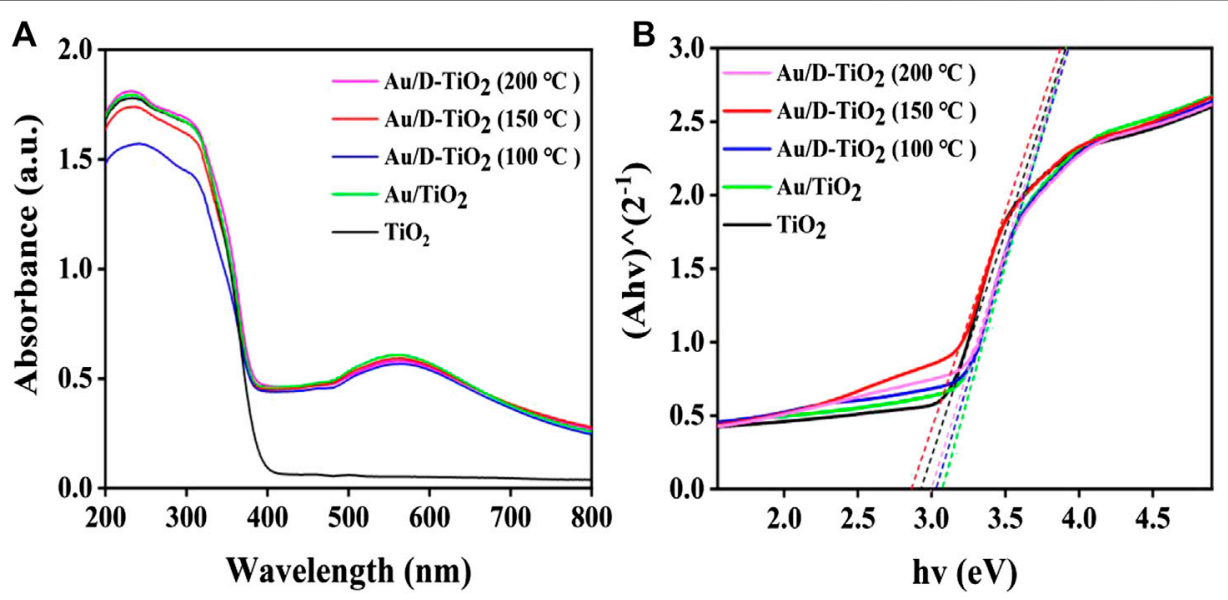

FIGURE 4 | (A) UV-vis DRS of synthesized of $\mathrm{TiO}_{2}, \mathrm{Au} / \mathrm{TiO}_{2}$ and $\mathrm{Au} / \mathrm{D}-\mathrm{TiO}_{2}$ (The D- $\mathrm{TiO}_{2}$ were treated at $100^{\circ}, 150^{\circ}$, and $200^{\circ} \mathrm{C}$, respectively) (B) the forbidden band width of synthesized of $\mathrm{TiO}_{2}, \mathrm{Au} / \mathrm{TiO}_{2}$, and $\mathrm{Au} / \mathrm{D}-\mathrm{TiO}_{2}$ (The $\mathrm{D}-\mathrm{TiO}_{2}$ were treated at $100^{\circ}, 150^{\circ}$, and $200^{\circ} \mathrm{C}$, respectively).

were not obvious differences. The $\mathrm{Au} 4 \mathrm{f}$ of $\mathrm{Au} / \mathrm{D}-\mathrm{TiO}_{2}$ (treated at $150^{\circ} \mathrm{C}$ ) core-level XPS spectrum displayed one special peak at $83.9 \mathrm{eV}$ in Figure 3D, and this peak could be attributed to $\mathrm{Au}$ clusters $[26,27]$.

The measurements of UV-visible diffuse-reflectance spectrum (UV-vis DRS) were carried out to investigate the light absorption intensity. As can be seen from Figure 4A, the intensity of light absorption for $\mathrm{Au} / \mathrm{D}-\mathrm{TiO}_{2}$ was significantly enhanced in the wavelength ranging from 250 to $800 \mathrm{~nm}$ compared with the untreated $\mathrm{TiO}_{2}$ nanosheets. And $\mathrm{Au} / \mathrm{D}-\mathrm{TiO}_{2}$ (treated at $150^{\circ} \mathrm{C}$ ) showed the strongest absorption intensity. According to the UVvis DRS, the optical band gap value $E_{g}$ of all samples was estimated from these absorption profiles using the Tauc's relation (Figure 4B) [28]. As shown in Figure 4B, the band gaps of these samples were analogous. However, after combining with $\mathrm{Au}$ clusters, the band gap of the samples mildly narrowed, whereby the results of pure $\mathrm{TiO}_{2}, \mathrm{Au} / \mathrm{TiO}_{2}, \mathrm{Au} / \mathrm{D}-\mathrm{TiO}_{2}$ (treated at $100^{\circ} \mathrm{C}$ ), $\mathrm{Au} / \mathrm{D}-\mathrm{TiO}_{2}$ (treated at $150^{\circ} \mathrm{C}$ ) and $\mathrm{Au} / \mathrm{D}-\mathrm{TiO}_{2}$ (treated at $200^{\circ} \mathrm{C}$ ) were $2.93,3.05,3.03,2.86$ and $2.98 \mathrm{ev}$, respectively $[29,30]$.

Figure 5 presented a comparison of the PL spectra of synthesized $\mathrm{TiO}_{2}$ and $\mathrm{Au} / \mathrm{D}-\mathrm{TiO}_{2}$ (The $\mathrm{D}-\mathrm{TiO}_{2}$ were treated at $100^{\circ}, 150^{\circ}$, and $200^{\circ} \mathrm{C}$, respectively). PL emission in semiconductors was due to the recombination of free carriers. The PL peak at about $396 \mathrm{~nm}$ was attributed to the emission of the bandgap transition. At an excitation wavelength of $230 \mathrm{~nm}$, the light energy was approximately equal to the bandgap energy of anatase $(387 \mathrm{~nm})$. As expected, the PL intensity of the prepared $\mathrm{Au} / \mathrm{D}-\mathrm{TiO}_{2}$ was significantly reduced as compared with pure $\mathrm{TiO}_{2}$. This indicated that the recombination rate of electrons and holes of $\mathrm{Au} / \mathrm{D}-\mathrm{TiO}_{2}$ sample was low. This might be owing to the fact that electrons were excited from the valence band to the conduction band, and then moved to $\mathrm{Au}$, thereby preventing the direct recombination of electrons and holes. In general, low recombination rate of electrons and holes are often associated with high photocatalytic activity [31,32].

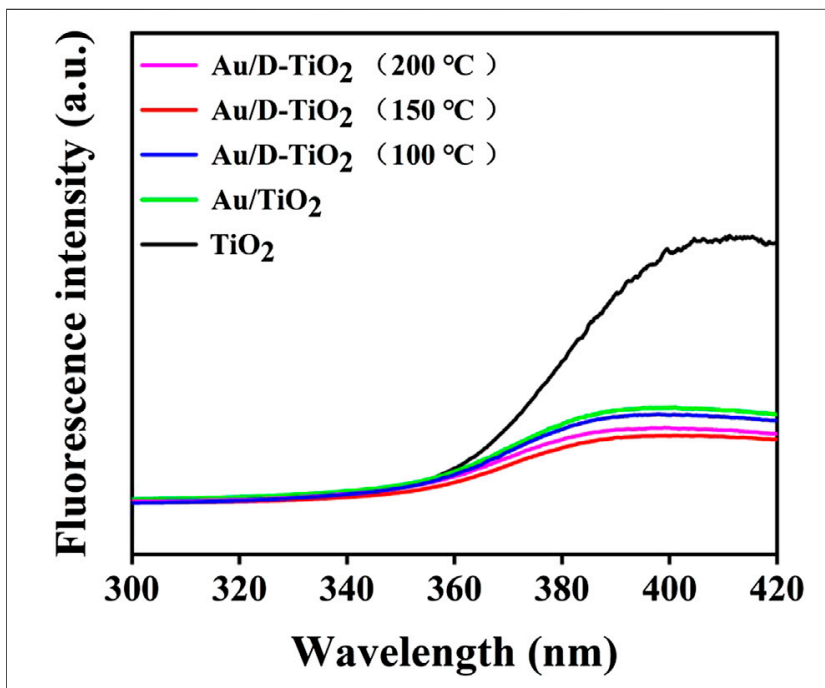

FIGURE 5 | PL spectra of $\mathrm{TiO}_{2}, \mathrm{Au} / \mathrm{TiO}{ }_{2}$ and $\mathrm{Au} / \mathrm{D}-\mathrm{TiO}_{2}$ (The D-TiO were treated at $100^{\circ}, 150^{\circ}$, and $200^{\circ} \mathrm{C}$, respectively).

In order to understand the band structure change of $\mathrm{TiO}_{2}$ nanosheets after Au loading, the Mott-Schottky experiment (MS) was conducted (Figure 6).

Based on the MS equation, the capacitance (C) depend on applied potential and could be fitted as follows [33]:

$$
\frac{1}{C^{2}}=+\frac{2}{e \varepsilon \varepsilon_{0} N_{d}}\left(E-E_{F B}-\frac{k_{b}}{e}\right)
$$

Where the slope expresses the type of semiconductor (negative to p-type and positive to n-type). The $N_{d}$ denotes the carrier density. The $C, E$ (corrected by the $\mathrm{AgCl}$ vs $0.197 \mathrm{eV}$ ) denote the space charge capacitance and applied potential. $\varepsilon$ denotes the relative permittivity. $\varepsilon_{0}$ denotes the vacuum permittivity. Where $e$ 
denotes the electron charge. Besides, the intercept on the $x$ axis denotes the $E_{f b}$ (band potential).

As revealed in Figure 6, the positive slope in the Mott-Schottky plot for the samples indicated that $\mathrm{TiO}_{2}$ nanosheets was typical n-type semiconductors according to the MS equation. Furthermore, the conduction band (CB) of the samples were obtained corrected by the $\mathrm{AgCl}$ by calculating, and the flat band potential $\left(E_{f b}(\mathrm{Vs} \mathrm{RHE})\right.$ ) of pure $\mathrm{TiO}_{2}, \mathrm{Au} / \mathrm{TiO}_{2}, \mathrm{Au} /$ $\mathrm{D}-\mathrm{TiO}_{2}$ (treated at $100^{\circ} \mathrm{C}$ ), $\mathrm{Au} / \mathrm{D}-\mathrm{TiO}_{2}$ (treated at $150^{\circ} \mathrm{C}$ ) and $\mathrm{Au} /$ $\mathrm{D}-\mathrm{TiO}_{2}$ (treated at $200^{\circ} \mathrm{C}$ ) were gained to be $-0.16,-0.13,-0.07$, -0.04 , and $-0.01 \mathrm{~V}$, respectively. Moreover, the valence band (VB) was calculated by adding the band gap value to the $\mathrm{CB}$ level. whereby the results of pure $\mathrm{TiO}_{2}, \mathrm{Au} / \mathrm{TiO}, \mathrm{Au} / \mathrm{D}-\mathrm{TiO}_{2}$

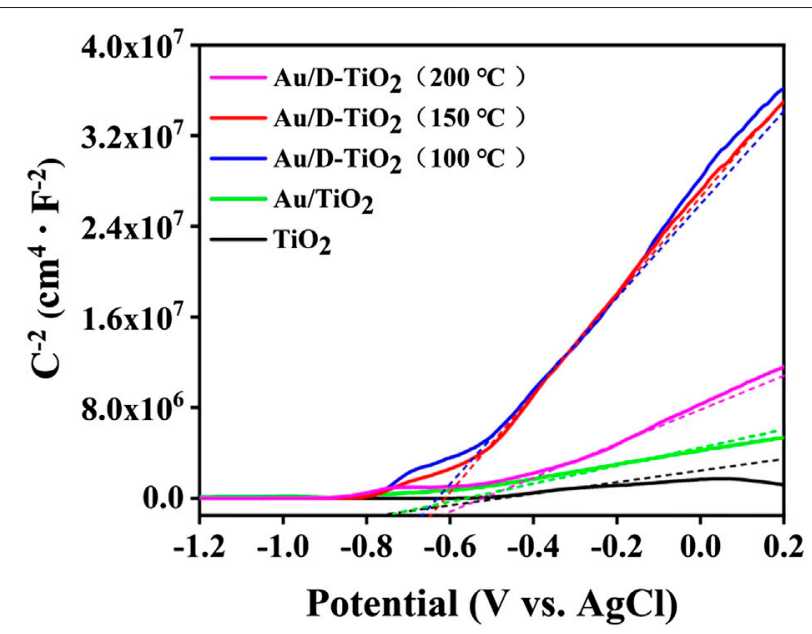

FIGURE 6 | The Mott-Schottky curves of using $\mathrm{Ag} / \mathrm{AgCl}$ as a reference electrode of $\mathrm{TiO}_{2}, \mathrm{Au} / \mathrm{TiO}_{2}$, and $\mathrm{Au} / \mathrm{D}-\mathrm{TiO}_{2}\left(\mathrm{The} \mathrm{D}-\mathrm{TiO}_{2}\right.$ were treated at $100^{\circ}$, $150^{\circ}$, and $200^{\circ} \mathrm{C}$, respectively). (treated at $100^{\circ} \mathrm{C}$ ), $\mathrm{Au} / \mathrm{D}-\mathrm{TiO}_{2}$ (treated at $150^{\circ} \mathrm{C}$ ) and $\mathrm{Au} / \mathrm{D}-\mathrm{TiO}_{2}$ (treated at $200^{\circ} \mathrm{C}$ ) were 2.77, 2.92, 2.96, 2.82, and $2.97 \mathrm{~V}$, respectively compared with NHE.

The photocatalytic $\mathrm{H}_{2}$ production activities of the bare $\mathrm{TiO}_{2}$, $\mathrm{Au} / \mathrm{TiO}_{2}$ and $\mathrm{Au} / \mathrm{D}-\mathrm{TiO}_{2}$ were further examined in Figure 7. Under the same experimental conditions, the test was performed every $1 \mathrm{~h}$, and a total of $4 \mathrm{~h}$ of experiments were performed. Bare $\mathrm{TiO}_{2}$ and $\mathrm{Au} / \mathrm{TiO}_{2}$ only exhibited a very low photocatalytic $\mathrm{H}_{2}$ production rate of 69.18 and $138.7 \mu \mathrm{mol} \mathrm{h}^{-1} \mathrm{~g}^{-1}$, respectively. However, after coupling with $\mathrm{Au}$ clusters, the production rate of photocatalytic $\mathrm{H}_{2}$ was significantly enhanced. $\mathrm{Au} / \mathrm{D}-\mathrm{TiO}_{2}$ (treated at $150^{\circ} \mathrm{C}$ ) exhibited the highest photocatalytic $\mathrm{H}_{2}$ production rate of $3,142.33 \mu \mathrm{mol} \mathrm{h}{ }^{-1} \mathrm{~g}^{-1}$, suggesting that the construction of $\mathrm{Au} / \mathrm{D}-\mathrm{TiO}_{2}$ could effectively boost the production activity of photocatalytic $\mathrm{H}_{2}$. Besides, the production rate of photocatalytic $\mathrm{H}_{2}$ first increased and then declined when the treated temperature of $\mathrm{D}-\mathrm{TiO}_{2}$ increased from $100^{\circ}$ to $200^{\circ} \mathrm{C}$ for $\mathrm{Au} / \mathrm{D}-\mathrm{TiO}_{2}$ samples, indicating that the treated temperature could efficiently adjust the defects of $\mathrm{TiO}_{2}$ nanosheets and effect the $\mathrm{H}_{2}$ production activity [34-36].

The stability test with $\mathrm{Au} / \mathrm{D}-\mathrm{TiO}_{2}$ was carried out by a total of $16 \mathrm{~h}$ of cycling experiments, which were divided into four groups of $4 \mathrm{~h}$, respectively, and an injection was performed every hour for data recording. The result suggested a good stability of $\mathrm{Au} /$ $\mathrm{D}-\mathrm{TiO}_{2}$ at fully photocatalytic hydrogen production experiment process without obvious decrease, which might be due to the $\mathrm{Au}$ clusters could be effectively stabilized on $\mathrm{TiO}_{2}$.

A reaction mechanism for the evolution of hydrogen is shown in Figure 8. First, the valence band electrons of $\mathrm{TiO}_{2}$ are excited to the conduction band, and then immediately transferred to $\mathrm{Au}$ through the intimate interface contacts. Since it is well known that $\mathrm{H}_{2} \mathrm{O}$ has an ionization balance in the natural state, the water contains trace amounts of $\mathrm{H}^{+}$and $\mathrm{OH}^{-}$. Therefore, the releasing $\mathrm{H}^{+}$binding in the $\mathrm{e}^{-}$of $\mathrm{H}_{2} \mathrm{O}$ to produce $\mathrm{H}_{2} \cdot \mathrm{H}^{+}$adsorption on the surface of the $\mathrm{Au}$ and accepting excited electrons is a key step in the
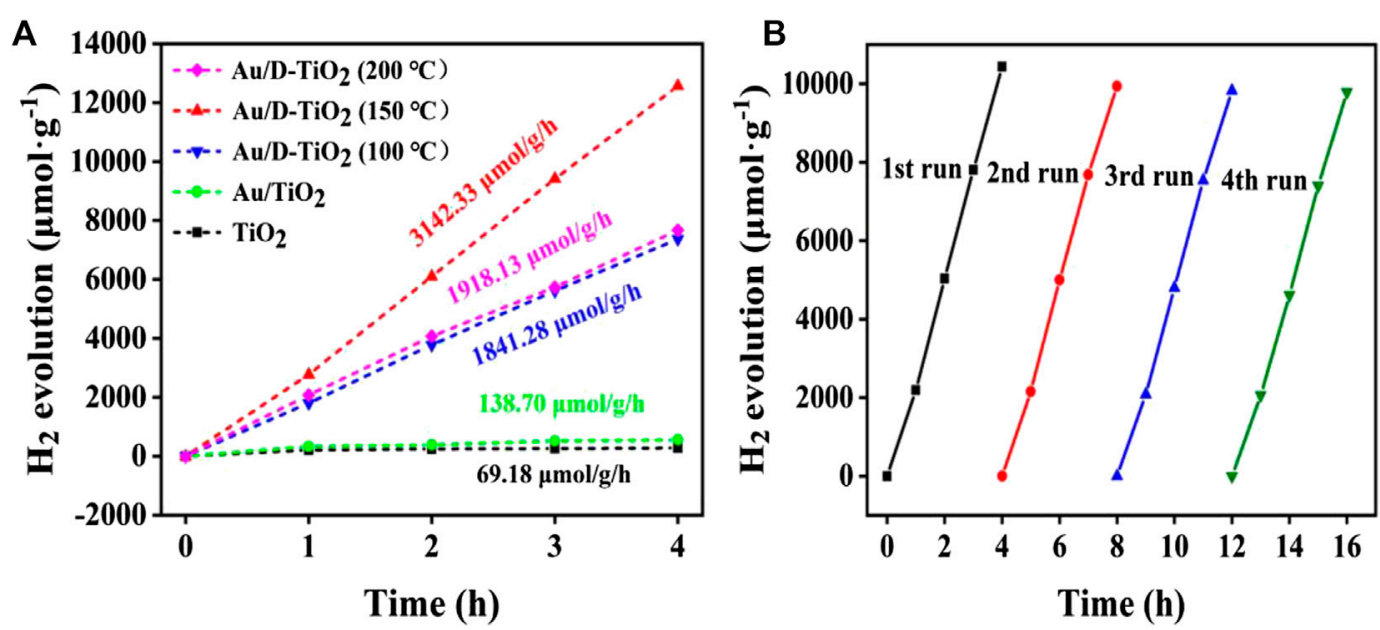

FIGURE 7 | (A) $\mathrm{H}_{2}$ production of $\mathrm{TiO}_{2}, \mathrm{Au} / \mathrm{TiO}_{2}$, and $\mathrm{Au} / \mathrm{D}-\mathrm{TiO}_{2}$ (The D- $\mathrm{TiO}_{2}$ were treated at $100^{\circ}, 150^{\circ}$, and $200^{\circ} \mathrm{C}$, respectively) under sunlight irradiation (B) Circulation experiment of hydrogen evolution of $\mathrm{Au} / \mathrm{D}-\mathrm{TiO}_{2}$ (treated at $150^{\circ} \mathrm{C}$ ). 


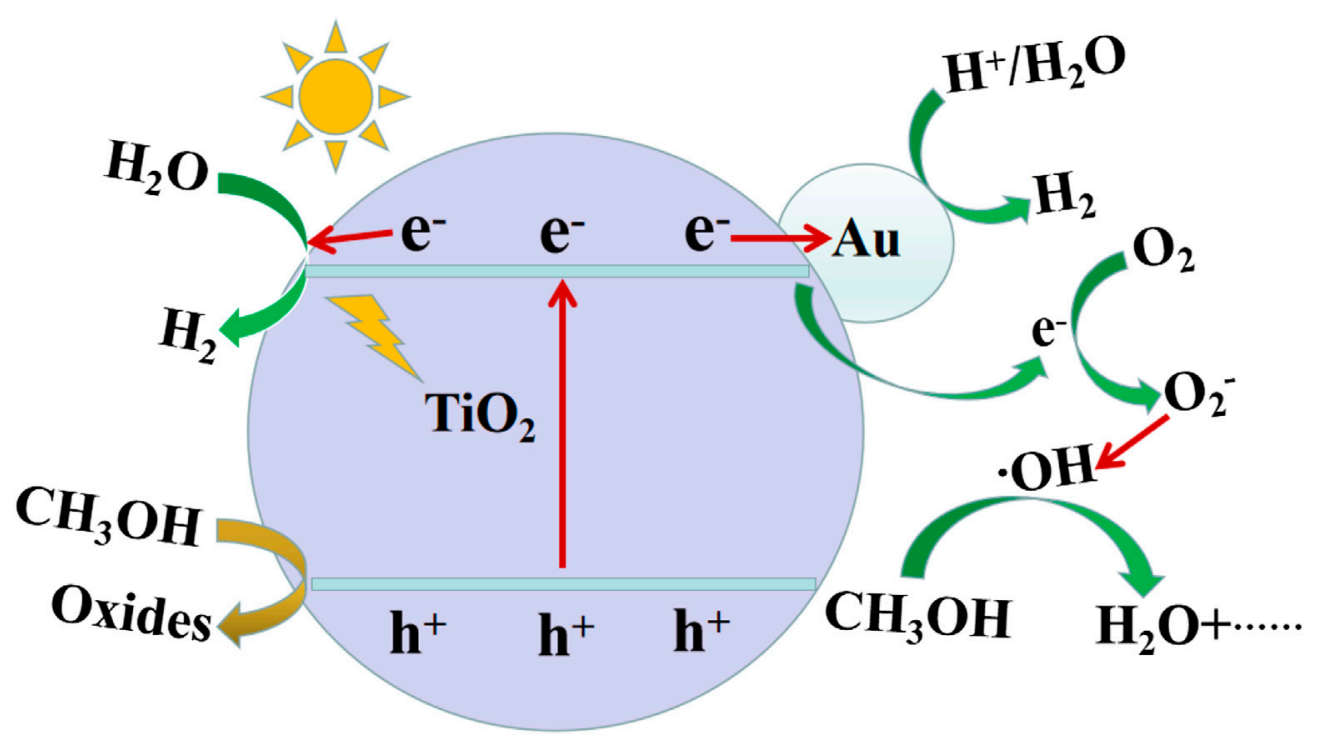

FIGURE 8 | Schematic diagram of charge transfer and $\mathrm{H}_{2}$ production of $\mathrm{Au} / \mathrm{D}-\mathrm{TiO}_{2}$.

hydrogen evolution reaction. On the other hand, $\mathrm{H}_{2} \mathrm{O} / \mathrm{OH}^{-}$reacts with $\mathrm{h}^{+}$in $\mathrm{Au} / \mathrm{D}-\mathrm{TiO}_{2}$ to produce $\mathrm{H}_{2}$ and $\mathrm{OH}$. When $\mathrm{H}_{2}$ is released, $\mathrm{O}_{2}$ is also formed. Then $\mathrm{O}_{2}$ reacts with the $\mathrm{e}^{-}$to form $\mathrm{O}_{2}{ }^{-}$. Finally, the $\mathrm{O}_{2}{ }^{-}$reacts with $\mathrm{CH}_{3} \mathrm{OH}$ to form $\mathrm{H}_{2} \mathrm{O}$. When $\mathrm{TiO}_{2}$ is coupled with Au clusters, it can provide more active sites for the hydrogen release reaction due to the characteristics of the $\mathrm{Au} /$ $\mathrm{D}-\mathrm{TiO}_{2}$ catalyst, thereby increasing photocatalytic activity [37, 38].

\section{CONCLUSION}

In conclusion, $\mathrm{Au}$ based on defective $\mathrm{TiO}_{2}$ nanosheets $\left(\mathrm{Au} / \mathrm{D}-\mathrm{TiO}_{2}\right)$ has been successfully prepared and applied to the production of photocatalytic hydrolysis hydrogen. Compared with bare $\mathrm{TiO}_{2}$ and $\mathrm{Au} / \mathrm{TiO}_{2}$ only exhibit a very low production rate of photocatalytic $\mathrm{H}_{2}$ of 69.18 and $138.7 \mu \mathrm{mol} \mathrm{h}{ }^{-1} \mathrm{~g}^{-1}$, respectively, the production rate of photocatalytic $\mathrm{H}_{2}$ was significantly enhanced after coupling with $\mathrm{Au}$ clusters. The $\mathrm{Au} / \mathrm{D}-\mathrm{TiO}_{2}$ treated at $150^{\circ} \mathrm{C}$ exhibited the highest production rate of photocatalytic $\mathrm{H}_{2}$ of $3,142.33 \mu \mathrm{mol} \mathrm{h}^{-1} \mathrm{~g}^{-1}$. The stability test suggested a good stability of $\mathrm{Au} / \mathrm{D}-\mathrm{TiO}_{2}$ at fully photocatalytic hydrogen production experiment process due to the $\mathrm{Au}$ clusters could be effectively stabilized on $\mathrm{TiO}_{2}$. Overall, this could be an effective approach for enhancing photocatalytic hydrogen production efficiency and stability by catalyst.

\section{REFERENCES}

1. Li L, Yu H, Xu J, Zhao S, Liu Z, Li Y. Rare earth element, Sm, modified graphite phase carbon nitride heterostructure for photocatalytic hydrogen production. New J Chem (2019) 43:1716-24. doi:10.1039/C8NJ05619F

2. Ismael $\mathrm{M}, \mathrm{Wu} \mathrm{Y}$, Wark M. Photocatalytic activity of $\mathrm{ZrO}_{2}$ composites with graphitic carbon nitride for hydrogen production under visible light. New J Chem (2019) 43:4455-62. doi:10.1039/C8NJ06507A

\section{DATA AVAILABILITY STATEMENT}

The original contributions presented in the study are included in the article/supplementary material, further inquiries can be directed to the corresponding authors.

\section{AUTHOR CONTRIBUTIONS}

XZ: Conducted experiments and wrote manuscript; WZ: Conducted experiments, evaluated data; YX: Designed experiments, evaluated data, and revised manuscript; MJ: Acquired research funding, conceived research and revised manuscript.

\section{FUNDING}

This work was financially supported by Guangdong Provincial Grant (2018A050506025), Special Fund Project of Science and Technology Application in Guangdong (2017B020240002), Guangdong Provincial Key Laboratory of Optical Information Materials and Technology (Grant No. 2017B030301007), Guangdong Innovative Research Team Program (No. 2016ZT06C517), Science and Technology Program of Guangzhou (No. 2019050001).

3. Liang Q, Cui S, Xu S, Yao C, Maclachlan MJ, Li Z. A porous triptycene-based covalent polymer stabilized binary metal sulfide for enhanced hydrogen evolution under visible light. Chem Comm (2018) 54:3391-4. doi:10.1039/ C8CC00665B

4. Zhang K, Guo L. Metal sulphide semiconductors for photocatalytic hydrogen production. Catal Sci Technol (2013) 3:1672. doi:10.1039/C3CY00018D

5. Martha S, Sahoo PC, Parida KM. An overview on visible light responsive metal oxide based photocatalysts for hydrogen energy production. RSC Adv (2015) 5: 61535-53. doi:10.1039/C5RA11682A 
6. Tian H, Cui X, Zeng L, Su L, Song Y, Shi J. Oxygen vacancy-assisted hydrogen evolution reaction of the $\mathrm{Pt} / \mathrm{WO}_{3}$ electrocatalyst. J Mater Chem A (2019) 7: 6285-93. doi:10.1039/C8TA12219A

7. Kumaravel V, Mathew S, Bartlett J, Pillai SC. Photocatalytic hydrogen production using metal doped $\mathrm{TiO}_{2}$ : a review of recent advances. Appl Catal B Environ (2019) 244:1021-64. doi:10.1016/j.apcatb.2018.11.080

8. Salimi M, Behbahani M, Sobhi HR, Gholami M, Jafari AJ, Kalantary RR, et al. A new nano-photocatalyst based on $\mathrm{Pt}$ and $\mathrm{Bi}$ co-doped $\mathrm{TiO}_{2}$ for efficient visiblelight photo degradation of amoxicillin. New J Chem (2019) 43:1562-8. doi:10. 1039/C8NJ05020A

9. Yunarti RT, Lee M, Hwang YJ, Choi J, Suh DJ, Lee J, et al. Transition metaldoped $\mathrm{TiO}_{2}$ nanowire catalysts for the oxidative coupling of methane. Catal Commun (2014) 50:54-8. doi:10.1016/j.catcom.2014.02.026

10. Kim J, Kwon G, Lim H, Zhu C, You H, Kim Y. Effects of transition metal doping in $\mathrm{Pt} / \mathrm{M}-\mathrm{TiO}_{2}(\mathrm{M}=\mathrm{V}, \mathrm{Cr}$, and $\mathrm{Nb})$ on oxygen reduction reaction activity. J Power Sources (2016) 320:188-95. doi:10.1016/j.jpowsour.2016.04.091

11. Li Y, Xu D, Oh JI, Shen WZ, Li X, Yu Y. Mechanistic study of codoped titania with nonmetal and metal ions: a case of $\mathrm{C}+\mathrm{Mo}$ codoped $\mathrm{TiO}_{2}$. ACS Catal (2012) 2:391-8. doi:10.1021/cs2006668

12. Yang G, Wang T, Yang B, Yan Z, Ding S, Xiao T. Enhanced visible-light activity of F-N co-doped $\mathrm{TiO}_{2}$ nanocrystals via nonmetal impurity, $\mathrm{Ti}^{3+}$ ions and oxygen vacancies. Appl Surf Sci (2013) 287:135-42. doi:10.1016/j.apsusc. 2013.09.094

13. Tian F, Zhu R, Ouyang F. Synergistic photocatalytic degradation of pyridine using precious metal supported $\mathrm{TiO}_{2}$ with $\mathrm{KBrO}_{3}$. J Environ Sci (2013) 25: 2299-305. doi:10.1016/S1001-0742(12)60304-0

14. Walsh FC, Bavykin DV, Torrentemurciano L, Lapkin AA, Cressey BA. Synthesis of novel composite materials via the deposition of precious metals onto protonated titanate $\left(\mathrm{TiO}_{2}\right)$ nanotubes. Trans IMF (2013) 84: 293-9. doi:10.1179/174591906X149077

15. Ooyama Y, Uenaka K, Sato T, Shibayama N, Ohshita J. Effective cosensitization using $\mathrm{D}-\pi-\mathrm{A}$ dyes with a pyridyl group adsorbing at Brønsted acid sites and Lewis acid sites on a $\mathrm{TiO}_{2}$ surface for dye-sensitized solar cells. RSC Adv (2015) 5:2531-5. doi:10.1039/C4RA14190C

16. Fajariah N, Prabowo WA, Fathurrahman F, Melati A, Dipojono HK. The investigation of electronic structure of transition metal doped $\mathrm{TiO}_{2}$ for diluted magnetic semiconductor applications: a first principle study. Procedia Eng (2017) 170:141-7. doi:10.1016/j.proeng.2017.03.032

17. Boga B, Szekely I, Pap Z, Baia L, Baia M. Detailed spectroscopic and structural analysis of $\mathrm{TiO}_{2} / \mathrm{WO}_{3}$ composite semiconductors. J Spectrosc (2018) 2018: 6260458. doi:10.1155/2018/6260458

18. Song S, Cheng B, Wu N, Meng A, Cao S, Yu J. Structure effect of graphene on the photocatalytic performance of plasmonic $\mathrm{Ag} / \mathrm{Ag}_{2} \mathrm{CO}_{3}-\mathrm{rGO}$ for photocatalytic elimination of pollutants. Appl Catal B Environ (2016) 181: 71-8. doi:10.1016/j.apcatb. 2015.07.034

19. Efimkin DK, Burg GW, Tutuc E, MacDonald AH. Tunneling and fluctuating electron-hole Cooper pairs in double bilayer graphene. Phys Rev B (2020) 101: 035413. doi:10.1103/PhysRevB.101.035413

20. Prades JD, Hernandezramirez F, Jimenezdiaz R, Manzanares M, Andreu T, Cirera A, et al. The effects of electron-hole separation on the photoconductivity of individual metal oxide nanowires. Nanotechnol (2008) 19:465501. doi:10.1088/0957-4484/19/46/465501

21. Qi K, Lv W, Khan I, Liu S. Photocatalytic $\mathrm{H}_{2}$ generation via CoP quantum-dotmodified $g-\mathrm{C}_{3} \mathrm{~N}_{4}$ synthesized by electroless plating. Chin J Catal (2020) 41: 114-21. doi:10.1016/S1872-2067(19)63459-5

22. Reddy NR, Bhargav U, Kumari MM, Cheralathan KK, Shankar MV, Reddy $\mathrm{KR}$, et al. Highly efficient solar light-driven photocatalytic hydrogen production over $\mathrm{Cu} / \mathrm{FCNTs}$-titania quantum dots-based heterostructures. J Environ Manag (2020) 254:109747. doi:10.1016/j.jenvman.2019.109747

23. Liu Q, Wang F, Lin H, Xie Y, Tong N, Lin J, et al. Surface oxygen vacancy and defect engineering of $\mathrm{WO}_{3}$ for improved visible light photocatalytic performance. Catal Sci Technol (2018) 17:399-406. doi:10.1039/C8CY00994E

24. Alsaad AM, Al-Bataineh QM, Qattan IA, Ahmad AA, Ababne A, Bataineh Z, et al. Measurement and ab-initio investigation of structural, electronic, optical and mechanical properties of sputtered aluminium nitrides thin films. Front Phys (2020) 8:115. doi:10.3389/fphy.2020.00115

25. Ye K, Li K, Lu Y, Guo Z, Ni N, Liu H, et al. An overview of advanced methods for the characterization of oxygen vacancies in materials. Trends Anal Chem (2019) 116: 102-8. doi:10.1016/j.trac.2019.05.002

26. Zhang Z, Qin J, Shi W, Liu Y, Zhang Y, Liu Y, et al. Enhanced power conversion efficiency of perovskite solar cells with an up-conversion material of $\mathrm{Er}^{3+}-\mathrm{Yb}^{3+}-\mathrm{Li}^{+}$tri-doped $\mathrm{TiO}_{2}$. Nanoscale Res Lett (2018) 13:147. doi:10. 1186/s11671-018-2545-y

27. Criado A, Lavela P, Ortiz GF, Tirado JL, Gzouli S, Edfouf Z, et al. CTABassisted synthesis of $\mathrm{C} @ \mathrm{Na}_{3} \mathrm{~V}_{2}\left(\mathrm{PO}_{4}\right)_{2} \mathrm{~F}_{3}$ with optimized morphology for application as cathode material for Na-ion batteries. Front Phys (2019) 7: 207. doi:10.3389/fphy.2019.00207

28. Xu Y, Zhang H, Li X, Wang W, Li J. Ag-encapsulated single-crystalline anatase $\mathrm{TiO}_{2}$ nanoparticle photoanodes for enhanced dye-sensitized solar cell performance. J Alloys Compd (2017) 95:1104-11. doi:10.1016/j.jallcom.2016. 10.236

29. Wang S, Li C, Wang T, Zhang P, Li A, Gong J. Controllable synthesis of nanotube-type graphitic $\mathrm{C}_{3} \mathrm{~N}_{4}$ and their visible-light photocatalytic and fluorescent properties. J Mater Chem A (2014) 2:2885. doi:10.1039/ C3TA14576J

30. Xu Y, Zhang H, Li X, Wu Q, Wang W, Li Z, et al. Investigation of the improved performance with ferrites in $\mathrm{TiO}_{2}$ dye-sensitized solar cell. Appl Surf Sci (2017) 424:245-50. doi:10.1016/j.apsusc.2017.04.210

31. Hisatomi T, Takanabe K, Domen K. Photocatalytic water-splitting reaction from catalytic and kinetic perspectives. Catal Lett (2014) 145:95-108. doi:10. 1007/s10562-014-1397-z

32. Yu X, Wang Y, Meng X, Yang J. Preparation and characterization of $\mathrm{Pd} / \mathrm{N}$ codoped $\mathrm{TiO}_{2}$ photocatalysts with high visible light photocatalytic activity. Chin J Catal (2013) 34:1418-28. doi:10.1016/S1872-2067(12)60597-X

33. Martin DJ, Reardon PJ, Moniz SJ, Tang J. Visible light-driven pure water splitting by a nature-inspired organic semiconductor-based system. J Am Chem Soc (2014) 136:12568-71. doi:10.1021/ja506386e

34. Akple MS, Low J, Wageh S, Alghamdi AA, Yu J, Zhang J, et al. Enhanced visible light photocatalytic $\mathrm{H}_{2}$-production of $\mathrm{g}-\mathrm{C}_{3} \mathrm{~N}_{4} / \mathrm{WS}_{2}$ composite heterostructures. Appl Surf Sci (2015) 358:196-203. doi:10.1016/j.apsusc. 2015.08.250

35. Li K, Lu X, Zhang Y, Liu K, Huang Y, Liu $\mathrm{H} \mathrm{Bi}_{3} \mathrm{TaO}_{7} / \mathrm{Ti}_{3} \mathrm{C}_{2}$ heterojunctions for enhanced photocatalytic removal of water-borne contaminants. Environ Res (2020) 185:109409. doi:10.1016/j.envres.2020.109409

36. Wei W, Tian Q, Sun H, Liu P, Zheng Y, Fan M, et al.. Efficient visible-lightdriven photocatalytic $\mathrm{H}_{2}$ evolution over $\mathrm{MoO}_{2}-\mathrm{C} / \mathrm{CdS}$ ternary heterojunction with unique interfacial microstructures. Appl Catal B Environ (2020) 260: 118153. doi:10.1016/j.apcatb.2019.118153

37. Xu Y, Wang X, Jin M, Kempa K, Shui L. Water splitting performance enhancement of the $\mathrm{TiO}_{2}$ nanorod array electrode with ultrathin black phosphorus nanosheets. Chem Electro Chem (2019) 7:96-104. doi:10.1002/ celc. 201901456

38. Huang Y, Guo Z, Liu H, Zhang S, Wang P, Lu J, et al. Heterojunction architecture of $\mathrm{N}$-doped $\mathrm{WO}_{3}$ nanobundles with $\mathrm{Ce}_{2} \mathrm{~S}_{3}$ nanodots hybridized on a carbon textile enables a highly efficient flexible photocatalyst. Adv Funct Mater (2019) 29:45. doi:10.1002/adfm.201903490

Conflict of Interest: The authors declare that the research was conducted in the absence of any commercial or financial relationships that could be construed as a potential conflict of interest.

Copyright (c) 2020 Zhang, Zhang, Xu and Jin. This is an open-access article distributed under the terms of the Creative Commons Attribution License (CC $B Y)$. The use, distribution or reproduction in other forums is permitted, provided the original author(s) and the copyright owner(s) are credited and that the original publication in this journal is cited, in accordance with accepted academic practice. No use, distribution or reproduction is permitted which does not comply with these terms. 